\title{
A Study on the Prevalance of Epilepsy in the Provincial Center of Erzurum Erzurum İlinde Epilepsi Prevalansı Çalışması
}

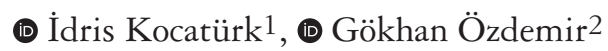 \\ ${ }^{1}$ Kastamonu State Hospital, Clinic of Neurology, Kastamonu, Turkey \\ 2Selcuk University Faculty of Medicine, Department of Neurology, Konya, Turkey
}

\begin{abstract}
Objective: Epilepsy is an important healthcare problem that occurs in every society across the world regardless of any difference in sex, age and ethnicity. Epidemiologic studies are important for providing a common ground and determining the factors associated with the disease. The objective of our study was to determine the prevalence of epilepsy for the population aged 15 years and over in the provincial center of Erzurum.

Materials and Methods: A questionnaire on epilepsy and a socio-demographic data form were administered to each patient by four assistant physicians who made door-to-door visits. The prevalence rate, distribution by age and sex, grading, treatment and familial characteristics of the disease were studied. We evaluated 4093 subjects aged 15 years and over.

Results: Of these subjects, $2046(50 \%)$ were female, and 2047 (50\%) were male. We identified 22 patients with active epilepsy with a point prevalence of $5 / 1000$ (4/1000 in female and 6/1000 in male patients). Fifty percent of patients had partial-onset seizures, and 50\% had generalized-onset seizures. The possible etiology was identified in $50 \%$ of patients. The most common identifiable etiology was cranial trauma and developmental brain malformation. Of these 22 patients, 20 (91\%) were on antiepileptic drugs (AEDs), $75 \%$ on a single AED, and $25 \%$ on multiple AEDs.

Conclusion: In the present study, the prevalence of active epilepsy and other characteristics were similar to those found in developed countries and studies in Turkey. The results can be attributed to careful use of International League Against Epilepsy guidelines and to the urban cohort.
\end{abstract}

Keywords: Epilepsy, epidemiology, prevalence

Öz

Amaç: Epilepsi, dünyada etnik köken, yaş ve cinsiyete bakılmaksızın önemli bir sağlık sorunudur. Hastalık ve hastalıkla ilişkili faktörleri tanımlamada epidemiyolojik çalışmalar önemlidir. Bizim bu çalışmada amacımız Erzurum ilinde 15 yaş ve üzeri insanlarda epilepsi prevalansını tanımlamaktır.

Gereç ve Yöntem: Bu çalışmamız 4 kişilik bir doktor ekibiyle yapıldı. Kapı kapı dolaşılarak epilepsi ve sosyo-demografik bilgiler kaydedildi. Epilepsi prevalansı, yaş ve cinsiyet, mezuniyet derecesi, aldığı tedavi ve ailesel karakteristikleri kaydedildi. Bu çalışmada 15 yaş ve üzeri 4093 kişi incelendi.

Bulgular: Çalışmaya alınan kişilerin 2046’sı (\%50) kadın, 2047’si (\%50) erkekti. Yirmi iki kişide epilepsi tanısı saptandı. Epilepsi prevalansı 5/1000 hesaplandı (kadın prevalansı 4/1000, erkek prevalansı 6/1000). Epilepsi hastalarının yarısı jeneralize nöbet geçirirken, diğer yarısı fokal nöbet geçiriyordu. Epilepsiye neden olan en önemli etiyolojik faktörler kraniyal travma ve gelişimsel nörolojik malformasyonlardı. Yirmi iki epilepsi hastasının 20'si (\%91) antiepileptik ilaç (AEİ) kullanıyordu. Bunların \%75'i tek AEİ kullanırken, \%25’i birden fazla AEİ alıyordu.

Sonuç: Epilepsi prevalansı ve karakteristik özellikleri gelişmiş ülkelerdeki oranlara benzerdi. Sonuç olarak çalışmamız epilepsi ile ilgili çalışmalarda ve epilepsi prevalansı ile ilgili konularda yol göstereceği kanaatindeyiz.

Anahtar Kelimeler: Epilepsi, epidemiyoloji, prevalans

Address for Correspondence/Yazışma Adresi: Gökhan Özdemir MD, Selcuk University Faculty of Medicine, Department of Neurology, Konya, Turkey Phone: +90 5301187786 E-mail: noro.ozdemir@gmail.com ORCID ID: orcid.org/0000-0001-8140-6333

Received/Geliş Tarihi: 08.04.2018 Accepted/Kabul Tarihi: 26.08.2018

๑Telif Hakkı 2019 Türk Nöroloji Derneği

Türk Nöroloji Dergisi, Galenos Yayınevi tarafından basılmıştır. 


\section{Introduction}

Epilepsy is an important public health problem, which is frequent worldwide without any differentiation in terms of ethnicity, sex and age, and has negative consequences on the educational, occupational and social activities of patients (1). Epilepsy is mostly misdiagnosed because it is unfamiliar to physicians, particularly in developing countries and rural areas, resulting in non-treatment or mistreatment of patients, which, in turn, as a major public health problem, has an impact on the economy of the countries and leads to social problems.

Epidemiologic studies are important for providing information about major issues such as prevalence, causes, treatment, prevention and consequences of the disease (2). Epidemiologic studies on epilepsy have been conducted in developed countries for many years, and the number of such studies has been increasing recently in developing countries. The lack of data on epidemiology of epilepsy in adults in our region has necessitated the present study.

The objective of our study was to determine the prevalence of epilepsy in a population aged 15 years and over at the provincial center of Erzurum. We planned to determine the prevalence of epilepsy using the protocols and criteria recommended by the World Health Organization (WHO) for prevalence studies in developing countries and the criteria from the Guidelines for Epidemiologic Studies on Epilepsy recommended by the Commission on Epilepsy and Prognosis of the International League Against Epilepsy (ILAE) (3).

\section{Materials and Methods}

The study was conducted in the province of Erzurum through door-to-door visits and face-to-face interviews. We selected 30 out of 121 primary care physicians working at the province center of Erzurum. Each physician included in sampling was considered a cluster. The target was to have 140 people for each cluster in order to reach to a total of 3707 people, which was calculated using the following formula (4):

$\mathrm{n}=\mathrm{Nt} 2 \mathrm{pq} / \mathrm{d} 2(\mathrm{~N}-1)+\mathrm{t} 2 \mathrm{pq}[95 \%$ confidence interval, (p) $2.5 \%$ (d) $0.5 \%$ ]

At the end of the study, we reached a total of 4093 people from 1300 households (2046 females and 2047 males). The aim of the study was to describe the participants before the interview, and a questionnaire was administered to those who volunteered to participate in the study.

The study was performed in three stages. A preliminary screening form was completed during the first stage to determine the socioeconomic characteristics of the patients such as sex, age, marital status, occupation, educational level, and medical history. During the second stage, a detailed questionnaire form was used taking the sociocultural structure and educational level of the local people into account based on the questionnaire form for the prevalence of epilepsy prepared by the WHO and questionnaire forms prepared by Karaagaç et al (5). The patients suspected of having epilepsy during the on-site screening were invited to the Epilepsy Outpatient Clinic to be evaluated by the relevant physicians. A detailed history was taken from these patients, and they underwent neurologic examinations and other assessments to ascertain the diagnosis. During the third stage, a detailed history was taken by phone from patients who rejected our invitation, and the archive records of those who were monitored by our faculty were reviewed. Each subject was evaluated thoroughly by physicians working on epilepsy, and included in the prevalence after establishing a final diagnosis.

The terminology of epilepsy, active epilepsy, epileptic seizure, and epilepsy in remission without treatment was defined according to the new operation classification seizure types by the ILAE (3). In the present study, we determined the prevalence of patients aged 15 years and over with active epilepsy, who had at least two seizures without any signal provided that the time between the two seizures was longer than 24 hours, and those who had at least one seizure in the past 5 years in the provincial center of Erzurum. The exogenous or metabolic causes, provoked and acute symptomatic seizures associated with alcohol and drug use, isolated febrile seizures and single seizures were excluded from the prevalence rate.

\section{Statistical Analysis}

Data were analyzed using the Statistical Package for the Social Sciences software program. The data are presented as number, percentage, mean, and standard deviation. The KolmogorovSmirnov test was used to determine if data were normally distributed. The chi-square test and Fisher's exact test were used for testing hypotheses. The significance level was set at $\mathrm{p}<0.005$.

\section{Results}

We found that among 4093 patients who underwent screening, there were active epilepsy in 22 patients, psychogenic nonepileptic seizures in 13 patients, and epilepsy in remission without treatment in 4 patients and syncope in 4 patients. The prevalence rate of active epilepsy was $0.5 \%$. When 4 patients with epilepsy in remission without treatment were also included, the total prevalence of epilepsy increased to $0.6 \%$. Of those 22 patients with active epilepsy, 9 were female and 13 were male. The prevalence was $0.4 \%$ in female patients vs. $0.6 \%$ in male patients. The difference was not statistically significant $(\mathrm{p}=0.393)$. When the prevalence of active epilepsy was evaluated by age groups, the highest prevalence was in the age groups of 15 to 25 years and 56 to 65 years with a rate of $0.7 \%$ in the entire study population. The lowest prevalence rate of active epilepsy was in the age group of 36 to 45 years with a rate of $0.3 \%$ (Table 1 ).

Clinical and electroencaphalography findings of patients diagnosed with active epilepsy were reviewed in order to determine the seizure types of 22 patients based on the 2017 ILAE seizure classification. Ten patients had multiple seizures. Among the 22 patients, 8 patients had 2 types of seizures and 2 patients had 3 types of seizures. Twelve patients had a single type of seizure. Of the 34 seizures that occured in 22 patients, 17 (50\%) were generalized-onset seizures and $17(50 \%)$ were focal-onset seizures. Of the generalized onset seizures, 16 were tonic-clonic, and 1 was a myoclonic seizure. Of the focal-onset types, the most common was focal type with awareness with a rate of $17.6 \%$.

The possible etiology in 11 patients (50\%) who were diagnosed as having active epilepsy was identified according to the new classification of ILAE. Seven of these 11 patients with an identified possible etiology were in the focal-onset epilepsy group. 
A review of possible etiologies for focal-onset epilepsies showed developmental brain malformation in two patients, stroke in two patients, cranial trauma in two patients, and mental and/or motor retardation in one patient, as possible etiologic causes (Table 2).

The onset age of epilepsy was 10 to 19 years with a rate of $69.2 \%$ in male patients, and $33.3 \%$ in female patients. An evaluation regarding the duration of disease in patients with active epilepsy showed that it was 10 years in $59.1 \%, 20$ years in $18.2 \%$, and 30 years in $9.1 \%$ of patients.

Twenty of 22 patients diagnosed as having active epilepsy were using antiepileptic drugs (AEDs) regularly. Two patients discontinued AED treatment although they had seizures. While $75 \%$ of patients were on monotherapy, $25 \%$ were receiving polytherapy. The most frequently used drugs were carbamazepine and valproic acid with 10 patients each. Ten (45.5\%) out of 22 patients obtained substantial benefit while nine patients $(40.9 \%)$ had partial benefit (Table 3).

The first- and/or second-degree relatives of 4 (14.3\%) patients had active epilepsy. Compared with patients without epilepsy in the study population, patients with epilepsy had a significantly higher $(\mathrm{p}<0.0001)$ family burden. Three $(13.6 \%)$ of the 22 patients with active epilepsy had a history of febrile convulsions during their childhood. Among 4071 non-epileptic patients, 24 (0.6\%) had an experience of febrile convulsion during their childhood. The difference was statistically significant $(\mathrm{p}<0.0001)$.

Among our 22 patients with active epilepsy, 13 (59.1\%) were graduated from an elementary school, 5 from a high school, 3 from a university, and 1 patient was illiterate.

\section{Discussion}

Screening of 4093 patients by using a questionnaire on epilepsy and a socio-demographic data which was administered to each patient with door-to-door visits in province of Erzurum determined that prevalence rate of active epilepsy was $0.5 \%$.

In prevalence studies in Europe, the lowest rate was reported as $0.27 \%$ in a study by Rocca et al. (6), and the highest rate was $0.76 \%$ as reported in a study in the Faroe Islands by Joenson in 1986 (7). Frequency of epilepsies in other countries were summarized in Table $4(8,9,10,11,12,13,14,15)$. Studies on the prevalence of epilepsy in Turkey showed the highest rate in the rural areas of the Sivas Province at $1.7 \%$ (16). Other epidemoloigical studies in our country showed similar rates $(16,17,18,19,20,21,22$, 23 ) but methodologic differences may be play a significant role in

\begin{tabular}{|lccccccccc|}
\hline \multicolumn{4}{|c}{ Table 1. The distribution of patients with active epilepsy by age and sex in the whole study population } \\
Age groups & Number & Epilepsy & Prevalance & Number & Epilepsy & Prevalance & Number & Epilepsy \\
$15-25$ & 567 & 1 & 0.2 & 618 & 7 & 1.1 & 1185 & 8 \\
$26-35$ & 457 & 1 & 0.2 & 446 & 4 & 0.9 & 903 & 5 \\
$36-45$ & 386 & 2 & 0.5 & 309 & 0 & 0 & 695 & 2 \\
$46-55$ & 323 & 2 & 0.6 & 333 & 1 & 0.3 & 656 & 3 \\
$56-65$ & 184 & 2 & 1.1 & 223 & 1 & 0.4 & 407 & 3 \\
$66+$ & 129 & 1 & 0.8 & 118 & 0 & 0 & 247 & 1 \\
Total & 2046 & 9 & 0.4 & 2047 & 13 & 0.6 & 4093 & 22 \\
\hline
\end{tabular}

\begin{tabular}{|c|c|c|c|c|c|}
\hline \multirow[t]{2}{*}{ Possible etiology } & \multicolumn{2}{|c|}{$\begin{array}{l}\text { Focal- } \\
\text { onset } \\
\text { seizures }\end{array}$} & \multicolumn{2}{|c|}{$\begin{array}{c}\text { Generalized- } \\
\text { onset } \\
\text { seizures }\end{array}$} & \multirow{2}{*}{$\begin{array}{c}\text { Total } \\
\text { n }\end{array}$} \\
\hline & $\mathrm{n}$ & $\%$ & $\mathrm{n}$ & $\%$ & \\
\hline Cerebral anoxia & 0 & 0.0 & 1 & 10.0 & 1 \\
\hline $\begin{array}{l}\text { Developmental brain } \\
\text { malformation }\end{array}$ & 2 & 16.7 & 1 & 10.0 & 3 \\
\hline Stroke & 2 & 16.7 & 0 & 0.0 & 2 \\
\hline Cranial trauma & 2 & 16.7 & 1 & 10.0 & 3 \\
\hline $\begin{array}{l}\text { Central nervous system } \\
\text { infection }\end{array}$ & 0 & 0 & 1 & 10.0 & 1 \\
\hline $\begin{array}{l}\text { Mental and/or motor } \\
\text { retardation }\end{array}$ & 1 & 8.3 & 0 & 0.0 & 1 \\
\hline Etiology unknown & 5 & 41.6 & 6 & 60.0 & 11 \\
\hline Total & 12 & 100 & 10 & 100 & 22 \\
\hline
\end{tabular}

Table 3. Distribution of antiepileptic drugs used by patients with active epilepsy

\begin{tabular}{lccc} 
Antiepileptic drugs & \multicolumn{2}{c}{ Monotherapy } & Polytherapy \\
Carbamazepine & $\mathbf{n}$ & $\%$ & $\mathbf{n}$ \\
Valproic asid & 6 & 27.3 & 4 \\
Fhenytoin & 6 & 27.3 & 4 \\
Levetiracetam & 0 & 0 & 2 \\
Oxcarbazepine & 0 & 0 & 2 \\
Topiramate & 1 & 4.5 & 0 \\
Lamotrigine & 1 & 4.5 & 0 \\
Clonazepam & 0 & 0 & 1 \\
\hline
\end{tabular}


Table 4. The studies reporting the epilepsy prevalence from Turkey and Worldwide

\begin{tabular}{|c|c|c|c|}
\hline & $\begin{array}{l}\text { Population } \\
\text { from }\end{array}$ & $\begin{array}{l}\text { Population } \\
\text { incleded }\end{array}$ & $\begin{array}{l}\text { Active } \\
\text { epilepsy }\end{array}$ \\
\hline Aziz et al. (29) & $\begin{array}{l}\text { Ankara } \\
\text { Turkey }\end{array}$ & 11,497 & 81 \\
\hline Topalkara et al. (17) & $\begin{array}{l}\text { Sivas city, } \\
\text { Turkey }\end{array}$ & 5294 & 32 \\
\hline Karaagaç et al. (5) & $\begin{array}{l}\text { Silivri, } \\
\text { Turkey }\end{array}$ & 4803 & 49 \\
\hline Onal et al. (18) & $\begin{array}{l}\text { Istanbul city, } \\
\text { Turkey }\end{array}$ & 2187 & 17 \\
\hline Calişir et al. (19) & $\begin{array}{l}\text { Bursa city, } \\
\text { Turkey }\end{array}$ & 2116 & 18 \\
\hline Velioglu et al. (23) & $\begin{array}{l}\text { Trabzon, } \\
\text { Turkey }\end{array}$ & 5254 & 28 \\
\hline Kilınçer et al. (20) & $\begin{array}{l}\text { Denizli city, } \\
\text { Turkey }\end{array}$ & 4666 & 27 \\
\hline Keränen et al. (30) & Finland & 178,073 & 1129 \\
\hline Aziz et al. (14) & Pakistan & 24,130 & 241 \\
\hline $\begin{array}{l}\text { Olafsson and Hauser } \\
\text { (27) }\end{array}$ & Iceland & 89,656 & 428 \\
\hline Forsgren (25) & Sweden & 129,005 & 713 \\
\hline Kun et al. (31) & Singapore & 20,542 & 108 \\
\hline Oun et al. (32) & Estonia & 75,245 & 396 \\
\hline Melcon et al. (9) & Argentina & 17,049 & 64 \\
\hline
\end{tabular}

the difference in frequencies. Among these differences, inclusion of single seizures, febrile seizures, and provoked seizures may be associated with higher prevalence rates. In order to eliminate such differences, the ILAE standardized the definitions in the guidelines published in 2017, and recommended using these definitions in studies.

Studies on the prevalence of epilepsy in Turkey showed the highest rate in the rural areas of the Sivas province at $1.7 \%$ (16). In a study by Topalkara et al. (17) in the provincial center of Sivas, the lifetime prevalence was $0.63 \%$. A study in the rural areas of the Istanbul Province found a rate of $1 \%$, and another study including all other age groups reported a prevalence of $0.59 \%$ for active epilepsy $(5,18)$. A study in the provincial center of Bursa reported a lifetime epilepsy prevalence of $1.2 \%$ and an active epilepsy prevalence of $0.85 \%$, and a study conducted in the provincial center of Denizli showed that the epilepsy prevalence was $0.57 \%$ and the lifetime prevalence was $0.72 \%(19,20)$. In Ankara, the rate of active epilepsy was $0.7 \%$ (21). A study in Kirikkale found an active epilepsy prevalence rate of $0.46 \%$ (22). In Trabzon, the lifetime prevalence was $0.6 \%$, and the active epilepsy prevalence was $0.5 \%$ (23).

Studies on the prevalence of epilepsy indicate that the rates are generally higher in developing countries. The prevalence of epilepsy is particularly high in several African countries. Parasitic infections, particularly neurocysticercosis, are important etiologic factors for epilepsy in many of these countries. Other reasons for the high prevalence include intracranial infections of bacterial or viral origin, perinatal brain damage, head injuries, toxic agents, and hereditary factors (24). Methodologic differences may also play a significant role in the difference in frequencies. Among these differences, inclusion of single seizures, febrile seizures, and provoked seizures may be associated with higher prevalence rates. In order to eliminate such differences, the ILAE standardized the definitions in the guidelines published in 2017, and recommended using these definitions in studies. Our results are similar to prevalence rates observed in developed countries. This may be attributed to our urban cohort, use of door-to-door visit methods, and use of the ILAE 2017 criteria. In some societies such as the Turkish society, problems of patients with epilepsy in living alone, employment, participation in social activities, driving, and marriage may mask the disease, resulting in lower prevalence rates.

In the present study, the prevalence rate of active epilepsy was higher in male $(0.6 \%)$ patients than in female $(0.4 \%)$ patients. However, the difference was not statistically significant $(\mathrm{p}=0.393)$. Studies across the world showed that in general the prevalence of epilepsy was higher in men than in women. However, the difference rarely achieved statistical significance. It is also similar for studies conducted in Turkey.

In our study, the highest prevalence was in the age groups of 15 to 25 years and 56 to 65 years with $0.7 \%$. The result was similar to those observed in previous studies. Several European studies showed that the prevalence of epilepsy was lower after the age of 70 years, and the decline was attributed to the fact that other causes leading to paroxysmal impairment of consciousness in the elderly population interfered with the diagnosis of epilepsy, and unhealthy elderly people are not accessible during on-site studies (25). Similarly, the prevalence was higher in the 56 to 65 years age group, and there was a decline in the older age group. We found that $63.6 \%$ of our patients had epilepsy during their first 20 years. A study in Pakistan reported that the onset of disease was before 18 years of age in $74.3 \%$ of patients (14). A study in Libya showed that $63.4 \%$ of patients developed the disease during the first 20 years (26). The onset age in developed countries was lower compared with developing countries. It may be attributed to the fact that infections of the central nervous systems and perinatal problems are more frequent in developing countries. Accordingly epilepsy may develop at an earlier age.

The current study found that the disease was present in only $22.7 \%$ of patients for more than 20 years. A study by Olafsson and Hauser (27) showed that $25 \%$ of patients were exposed to the disease for more than 20 years, whereas a study in Trabzon reported it as $50 \%$ (23). The rate in the present study was lower compared with the other rates in our country, but similar to those in developed countries. Again, this may be associated with the study having been conducted in a provincial center, easier access to healthcare services because Erzurum is considered a regional health center, and the adequate number of neurologists in the region.

Seventy-five percent of our patients were on monotherapy and $25 \%$ were receiving polytherapy. Sixty percent of those who were on polytherapy were receiving triple-AED therapy and $40 \%$ were on double-AED therapy. The most preferred antiepileptics were valproic acid and carbamazepine. In the Honduras study, 58\% of patients were on monotherapy and new-generation antiepileptics 
were not available (8). In Sweden, $61 \%$ patients were on monotherapy and $30 \%$ were on polytherapy. Our study has shown that all patients were treated by neurologists (25). In Sicily, the differential diagnosis was made by neurologists in $70 \%$, and by primary care physicians in $23 \%$ of patients (6).

In the our study, 4 of 22 patients (18.2\%) with active epilepsy had first-degree relatives with active epilepsy. When compared with non-epileptic patients; patients with epilepsy had significantly higher familial characteristics $(\mathrm{p}<0.001)$.

The literature shows that the prevalence of epilepsy is significantly higher in siblings and children of epileptic people compared with other individuals in the population $(28,29,30,31,32) ; 13.6 \%$ of patients with active epilepsy had a history of febrile convulsion during childhood, which was statistically significant compared with non-epileptic patients $(\mathrm{p}<0.01)$. Studies have shown that individuals who experienced febrile convulsions during childhood were more likely to have epilepsy in advanced ages compared with the normal population. The risk for epilepsy varies between 1 to $6 \%$ in patients who experienced febrile convulsions. A study conducted in Sivas showed that $38.5 \%$ of patients with active epilepsy had a history of febrile convulsions when individulas aged younger than 20 years of age were evaluated, which was statistically significant.

\section{Conclusion}

As conclusion, in our study, the prevalence of active epilepsy and other characteristics were similar to those found in developed countries. The result can be attributed to careful use of ILAE guidelines and to the urban cohort. We conclude that our study will lead to issues related to the prevalence of epilepsy and studies of epilepsy.

\section{Ethics}

Ethics Committee Approval: The study were approved by the Ataturk University of Local Ethics Committee (Protocol number: 211).

Informed Consent: Consent form was filled out by all participants.

Peer-review: Externally and internally peer-reviewed.

\section{Authorship Contributions}

Surgical and Medical Practices: İ.K., G.Ö., Concept: İ.K., G.Ö., Design: İ.K., G.Ö., Data Collection or Processing: İ.K., G.Ö., Analysis or Interpretation: İ.K., G.Ö., Literature Search: İ.K., Writing: İ.K., G.Ö.

Conflict of Interest: No conflict of interest was declared by the authors.

Financial Disclosure: The authors declared that this study received no financial support.

\section{References}

1. Boling W, Means M, Fletcher A. Quality of Life and Stigma in Epilepsy, Perspectives from Selected Regions of Asia and Sub-Saharan Africa. Brain Sci $2018 ; 8$.

2. Argumosa A, Herranz JL. Economic aspects of epilepsy. Rev Neurol 2000;(30 Suppl 1):S154-60.

3. Zelano J, Stödberg T, Tomson T. Classification of seizures and epilepsies. Lakartidningen 2018;115.

4. Young, P. V. (1968). Bilimsel sosyal incelemeler ve araştırma (Çev. G. Bingöl ve N. İş̧̧il). Ankara: Ege Matbaası.
5. Karaagaç N, Yeni SN, Senocak M, Bozluolçay M, Savrun FK, Ozdemir H, Cagatay P. Prevalence of epilepsy in Silivri, a rural area of Turkey. Epilepsia 1999; 40:637-642.

6. Rocca WA, Savettieri G, Anderson DW, et al; Sicilian Neuro-Epidemiologic Study (SNES) Group. Door-to-door prevalence survey of epilepsy in three Sicilian municipalities. Neuroepidemiology 2001;20:237-241.

7. Joensen P. Prevalence, incidence, and classification of epilepsy in the Faroes. Acta Neurol Scand 1986;74:150-155.

8. Medina MT, Durón RM, Martínez L, et al. Prevalence, incidence, and etiology of epilepsies in rural Honduras: the Salamá Study. Epilepsia 2005;46:124131.

9. Melcon MO, Kochen S, Vergara RH. Prevalence and clinical features of epilepsy in Argentina. A community-based study. Neuroepidemiology 2007;28:8-15.

10. Osuntokun BO, Adeuja AO, Nottidge VA, et al. Prevalence of the epilepsies in Nigerian Africans: a community-based study. Epilepsia 1987;28:272-279.

11. Attia-Romdhane N, Mrabet A, Ben Hamida M. Prevalence of epilepsy in Kelibia, Tunisia. Epilepsia 1993;34:1028-1032.

12. Li SC, Schoenberg BS, Wang CC, et al. Epidemiology of epilepsy in urban areas of the People's Republic of China. Epilepsia 1985;26:391-394.

13. Bharucha NE. Epidemiology of epilepsy in India. Epilepsia 2003;(44 Suppl 1):9-11.

14. Aziz H, Ali SM, Frances P, Khan MI, Hasan KZ. Epilepsy in Pakistan: a population-based epidemiologic study. Epilepsia 1994;35:950-958.

15. Asawavichienjinda T, Sitthi-Amorn C, Tanyanont W. Prevalence of epilepsy in rural Thailand: a population-based study. J Med Assoc Thai 2002;85:1066-1073.

16. Özdemir Z. Prevalance and clinical features of epilepsy in rural area of Sivas province. Turkey In:Kırbaş D, Leonardi M, eds. Neurology and Public healths: Istanbul:Bitam Publications 1995:141-143.

17. Topalkara K, Akyüz A, Sümer H, et al. An Epilepsy Prevalence Study Performed using Strafitied Sampled Methodamong Urban Residents of Sivas. Epilepsi 1999;24-29.

18. Onal AE, Tumerdem Y, Ozturk MK, et al. Epilepsy prevalence in a rural area in Istanbul. Seizure 2002;11:397-401.

19. Calişir N, Bora I, Irgil E, Boz M. Prevalence of epilepsy in Bursa city center, an urban area of Turkey. Epilepsia 2006;47:1691-1699.

20. Kılınçer A, Erdoğan Ç, Ergin A, Acar G, Şahiner T. The prevalence of epilepsy in Denizli city center Pam Med J 2012;5:110-114.

21. Guvener A, Isık A, Ibars Z, Gelisen I Epidemiological, clinical and sociocultural aspects of epilepsy in a community based survey in central Anatolia Turkiye Klinikleri J Med Res 1990;8:151-159.

22. Erdemoğlu AK, Çakmak A, Saygun M, Varlıbaş A. Prevelance of Epilepsy in Adults of Kirıkkale Province Population, a Rural Area of Turkey. Türkiye Klinikleri J Neur 2010;5:1-7.

23. Velioglu SK, Bakirdemir M, Can G, Topbas M. Prevalence of epilepsy in northeast Turkey. Epileptic Disord 2010;12:22-37.

24. Senanayake N, Román GC. Epidemiology of epilepsy in developing countries. Bull World Health Organ 1993;71:247-258.

25. Forsgren L. Prevalence of epilepsy in adults in northern Sweden. Epilepsia 1992;33:450-458

26. Sridharan R, Radhakrishnan K, Ashok PP, Mousa ME. Epidemiological and clinical study of epilepsy in Benghazi, Libya. Epilepsia 1986;27:60-65.

27. Olafsson E, Hauser WA. Prevalence of epilepsy in rural Iceland: a populationbased study. Epilepsia 1999;40:1529-1534.

28. Ottman R, Annegers JF, Hauser WA, Kurland LT. Higher risk of seizures in offspring of mothers than of fathers with epilepsy. Am J Hum Genet $1988 ; 43: 257-264$

29. Aziz H, Güvener A, Akhtar SW, Hasan KZ. Comparative epidemiology of epilepsy in Pakistan and Turkey: Population based studies using identical protocols. Epilepsia 1997;38:716-722.

30. Keränen T, Riekkinen PJ, Sillanpää M. Incidence and prevalence of epilepsy in adults in eastern Finland. Epilepsia 1989;30:413-421.

31. Kun LN, Ling LW, Wah YW, Lian TT. Epidemiologic study of epilepsy in young Singaporean men. Epilepsia 1999;40:1384-1187.

32. Oun A, Haldre S, Mägi M. Prevalence of adult epilepsy in Estonia. Epilepsy Res 2003;52:233-242. 